\title{
STXBP2 Gene Mutation
}

National Cancer Institute

\section{Source}

National Cancer Institute. STXBP2 Gene Mutation. NCI Thesaurus. Code C158660.

A change in the nucleotide sequence of the STXBP2 gene. 